EVALUASI PERTUMBUHAN DAN IDENTIFIKASI JENIS HAMA PASAK BUMI (Eurycoma longifolia Jack) DI ARBORETUM SEMPAJA SAMARINDA Ngatiman, Deddy Dwi Nur Cahyono dan Lydia Suastati

\title{
EVALUASI PERTUMBUHAN DAN IDENTIFIKASI JENIS HAMA PASAK BUMI (Eurycoma longifolia Jack) DI ARBORETUM SEMPAJA SAMARINDA
}

\author{
( Growth evaluation and identification of caterpillar species on Pasak Bumi (Eurycoma longifolia \\ Jack) at Arboretum Sempaja Samarinda)

\begin{abstract}
*Ngatiman ${ }^{1}$, Deddy Dwi Nur Cahyono² dan/and Lydia Suastati $^{1}$
${ }^{1)}$ Balai Besar Penelitian dan Pengembangan Ekosistem Hutan Dipterokarpa

Jl. A. Wahab Syahrani No. 68 Sempaja Selatan, Kalimantan Timur, Indonesia

${ }^{2}$ Balai Penelitian dan Pengembangan Teknologi Perbenihan Tanaman Hutan

Jl. Pakuan Ciheuleut PO BOX 105; Telp 0251-8327768, Bogor, Indonesia

e-mail: deddydwi@yahoo.com
\end{abstract}

Naskah masuk: 3 September 2021; Naskah direvisi: 20 Oktober 2021; Naskah diterima: 24 Desember 2021

\section{ABSTRACT}

Pasak bumi (Eurycoma longifolia Jack) is a type of medicinal plant that was planted in the Sempaja Arboretum, Samarinda. The plant flowers and bears fruit every year. Problem found that it often experiences flowering, but only a small part of it becomes fruit. Besides that, there are also caterpillar infestation that attack the leaves, flowers and fruit of the pasak bumi. This research aims to evaluate the growth and identify species of caterpillar infestationon the pasak bumi at Arboretum Sempaja Samarinda. The research method is by measuring growth and species indentifying of caterpillar based on morphological feature that infestation for the period November 2019 to May 2021. The results of measurements on 25-year-old pasak bumi plants are $4.65 \mathrm{~m}$ high and $5.43 \mathrm{~cm}$ in diameter, with a height growth range of $0.17 \mathrm{~m}$ per year and 0.2 $\mathrm{cm}$ per year for diameter. Flowering occurred 6 times, but only $16.67 \%$ were able to produce fruit. The highest flowering was $91.67 \%$ in the November 2019 period, while the highest fruiting was $16.67 \%$ in May 2021. Atteva sciodoxa (Lepidoptera : Yponomeutidae) caterpillar infestation occurred in every flowering and fruiting period. The most caterpillar infestation were 91.67\% in November 2019 and the lowest was in November 2020 (33,34\%).

Keyword: Atteva scidoxa, Eurycoma longifolia, growth

\begin{abstract}
ABSTRAK
Pasak bumi (Eurycoma longifolia Jack) merupakan salah satu jenis tanaman berkhasiat obat yang ditanam di Arboretum Sempaja, Samarinda. Tanaman tersebut berbunga dan berbuah setiap tahun. Permasalahan yang ditemukan di lapangan adalah sering mengalami pembungaan, namun sebagian kecil saja yang menjadi buah. Disamping itu juga terdapat serangan ulat yang menyerang daun, bunga dan buah pasak bumi. Tulisan ini bertujuan untuk mengevaluasi pertumbuhan dan mengidentifikasi jenis ulat yang menyerang tanaman pasak bumi di Arboretum Sempaja Samarinda. Metode penelitian dengan melakukan evaluasi pertumbuhan dan identifikasi jenis ulat yang menyerang berdasarkan ciri morfologisnya pada saat terjadi pembungaan dan pembuahan periode November 2019 hingga Mei 2021. Hasil pengukuran pada tanaman pasak bumi yang berumur 25 tahun yaitu rata-rata tinggi $4,65 \mathrm{~m}$ dan diameter $5,43 \mathrm{~cm}$ dengan kisaran pertumbuhan tinggi $0,17 \mathrm{~m}$ per tahun dan diameter $0,2 \mathrm{~cm}$ per tahun. Terjadi pembungaan sebanyak 6 kali, namun hanya $16,67 \%$ saja yang dapat menghasilkan buah. Pembungaan terbanyak 91,67\% periode November 2019, sedangkan pembuahan terbanyak 16,67\% pada Mei 2021. Jenis ulat yang menyerang tanaman pasak bumi adalah Atteva sciodoxa (Lepidoptera : Yponomeutidae) yang terjadi pada setiap periode berbunga dan berbuah. Serangan ulat terbanyak 91,67\% pada November 2019 dan terendah pada November 2020 (33,34\%).
\end{abstract}

Kata kunci : Atteva scidoxa, Eurycoma longifolia, pertumbuhan

\section{PENDAHULUAN}

Pasak bumi merupakan salah satu tanaman yang dapat dimanfaatkan untuk pengobatan, yaitu sebagai afrodisiak, obat demam, tonikum, anti piretik, disentri, obat sakit kepala dan sakit perut (Riyani, 2016). Secara alami, sebaran pasak bumi di Indonesia mencakup Sumatera dan Kalimantan (Lim,

*Kontribusi penulis: Ngatiman sebagai kontributor utama 
2016). Di Sumatera diantaranya di Riau (Hasibuan et al., 2016), Tahura Sultan Syarif Hasyim Riau (Yunas et al., 2017), Taman Nasional Gunung Leuser Sumut (Andasari \& Navia, 2019), Kabupaten Langkat Sumut (Rahmawati et al., 2019), sedangkan di Kalimantan seperti di Kubu Raya Kalbar (Kartikawati, et al., 2014b) dan Kutai Timur Kaltim (Hadiah et al., 2019). Di Kalimantan, pasak bumi diperdagangkan dalam berbagai bentuk seperti potongan akar, serbuk, berupa gelas maupun ramuan. Pasak bumi kuning (Eurycoma longifolia Jack) merupakan jenis yang paling banyak diperdagangkan dibanding pasak bumi merah (Rennellia eliptika Korth) maupun pasak bumi hitam (Trivalvaria macrophylla Blume) (Supartini, 2016). Meskipun semua bagian tanaman pasak bumi dapat dimanfaatkan sebagai obat (Silalahi \& Nisyawati, 2015), namun pada umumnya yang dimanfaatkan adalah bagian akarnya. Adanya permintaan yang tinggi terhadap produk pasak bumi menyebabkan tekanan terhadap pasak bumi alam, hal ini karena bahan baku pasak bumi lebih banyak diambil dari alam yang kemudian berimplikasi pada ketersediaannya (Zuhud \& Hikmat, 2009; Kartikawati et al., 2014a). Tekanan keberadaan pasak bumi alam juga dari alih fungsi lahan yang menyebabkan kerusakan habitat (Hadiah et al., 2019).

Budidaya pasak bumi perlu segera dilakukan dalam skala komersial untuk memenuhi permintaan bahan baku dan mengurangi eksploitasi yang tidak terkendali. Budidaya perbanyakan pasak bumi dapat dilakukan secara generatif maupun vegetatif. Secara generatif yaitu dengan benih (Fitriani et al., 2017), cabutan (Cahyono \& Rayan, 2016) dan puteran (Suharti et al., 2013). Sedangkan secara vegetatif dapat menggunakan teknik stek pucuk (Susilowati et al., 2012), stek batang (Achmad, 2016) dan kultur jaringan (Rosmaina et al., 2015).

Tanaman pasak bumi yang berada di Arboretum Sempaja Samarinda saat ini telah berumur 25 tahun. Tanaman tersebut mulai berbunga dan berbuah pada umur 4 tahun dan selanjutnya mengalami pembungaan dan pembuahan setiap tahun. Perbanyakan menggunakan benih membutuhkan pengetahuan tentang pembungaan dan pembuahan dari pohon induk sebagai penghasil benih. Pemahaman informasi tersebut akan membantu memaksimalkan perolehan benih baik kualitas dan kuantitas melalui prediksi waktu panenan dan rasio bunga menjadi buah. Permasalahan yang terjadi di Arboretum Sempaja adalah pasak bumi sering mengalami pembungaan, namun beberapa pohon yang berbunga tersebut tidak menghasilkan buah. Disamping itu terdapat serangan ulat yang menyerang daun, bunga dan buah. Sebagai langkah awal, perlu diidentifikasi pohon-pohon yang selalu 
berbuah serta pohon-pohon yang diserang ulat. Tulisan ini bertujuan untuk mengevaluasi pertumbuhan pasak bumi dan mengidentifikasi jenis ulat yang menyerang tanaman pasak bumi di Arboretum Sempaja Samarinda.

\section{BAHAN DAN METODE}

\section{A. Alat dan Bahan}

Penelitian dilakukan di Arboretum Sempaja, Balai Besar Penelitian dan
Pengembangan Ekosistem Hutan Dipterokarpa Samarinda. Secara geografis terletak pada $0^{\circ} 27^{\prime} 08^{\prime \prime L S}$ dan $117^{\circ} 08^{\prime} 46^{\prime \prime B T}$ pada ketinggian 8 mdpl. Waktu penelitian dilakukan dari bulan November 2019 sampai dengan Mei 2021. Subyek pengamatan adalah tanaman pasak bumi (Eurycoma longifolia Jack) yang ada di Arboretum Sempaja Samarinda umur 25 tahun. Peralatan yang digunakan meliputi galah ukur, phiband dan kamera digital.

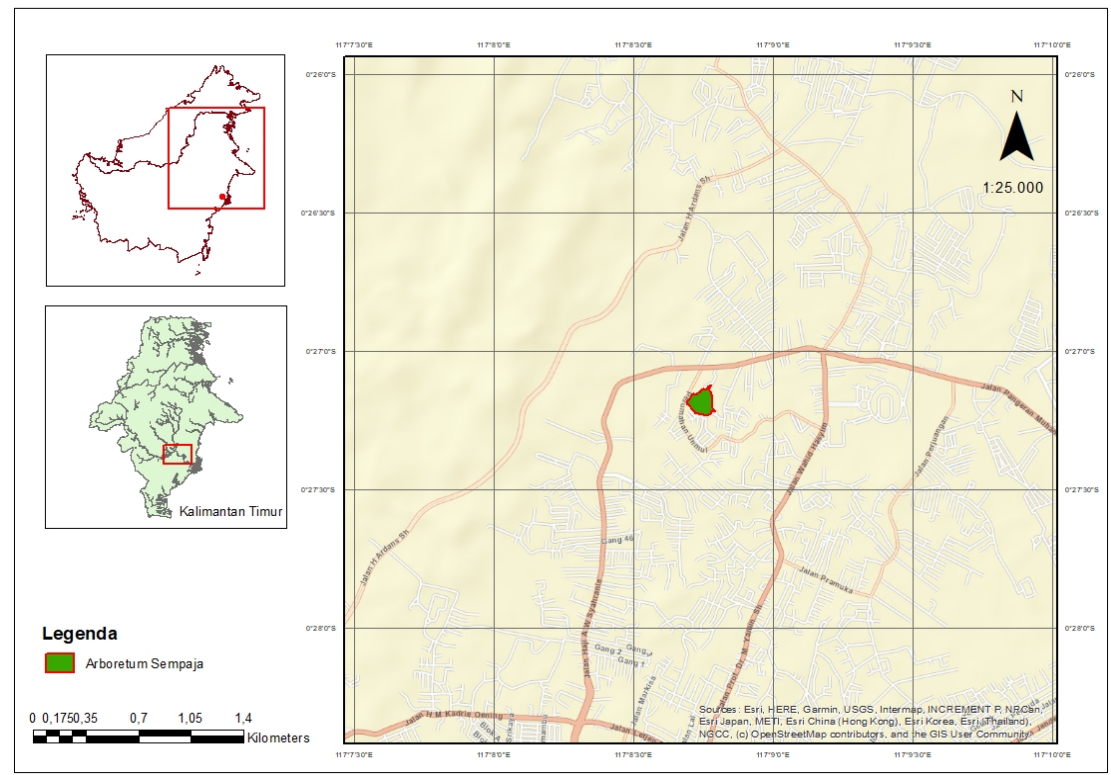

Gambar (Figure) 1. Lokasi arboretum Sempaja Samarinda (Arboretum Sempaja Samarinda location)

\section{B. Prosedur Penelitian}

\section{Penentuan pohon pengamatan.}

Seleksi secara purposive terhadap tegakan pasak bumi yang mengalami pembungaan, pembuahan dan terserang hama sebagai pengamatan pertama. Hasil seleksi awal, terpilih sebanyak 12 pohon sampel yang digunakan untuk bahan pengamatan selama proses penelitian.

\section{Pengamatan pertumbuhan.}

Pengukuran tinggi dan diameter 12 pohon terpilih serta penghitungan jumlah cabang dilakukan pada November 2019. Tinggi diukur mulai pangkal batang yang berbatasan dengan tanah sampai dengan pucuk daun tertinggi, sedangkan diameter diukur setinggi dada.

\section{Pengamatan pembungaan, pembuahan dan serangan hama.}


Jurnal Perbenihan Tanaman Hutan

Vol.9 No2 Desember 2021: 107-118

p-ISSN : 2354-8568

e-ISSN : 2527-6565

Dilakukan pendataan terhadap pohonpohon mana saja yang mengalami pembungaan, pembuahan dan terjadinya gejala serangan hama, baik itu serangan hama terhadap bunga maupun buah. Pengamatan dilakukan pada periode November 2019, April 2020, September 2020, November 2020, Desember 2020 dan Mei 2021.

\section{Identifikasi jenis.}

Pengambilan contoh larva pada pohonpohon pasak bumi yang terserang hama pada setiap periode pembungaan, kemudian larva diperlihara dalam wadah toples hingga tahap imago. Dilakukan pengamatan secara visual terhadap hama ulat. Ulat kemudian dilakukan identifikasi jenis di Pusat Penelitian Biologi LIPI berdasarkan ciri-ciri morfologinya (Nielsen \& Common, 1991; Robinson et al., 1994).

Tabel (Table) 1.Tinggi dan diameter pasak bumi (E. longifolia Jack) di Arboretum Sempaja, Samarinda (Height and diameter pasak bumi (E. longifolia Jack) at the Sempaja Arboretum, Samarinda)

\begin{tabular}{|c|c|c|c|}
\hline $\begin{array}{l}\text { Nomor Pohon } \\
\text { (Number of trees) }\end{array}$ & $\begin{array}{c}\text { Tinggi } \\
(\text { Height })(\mathrm{m})\end{array}$ & $\begin{array}{c}\text { Diameter } \\
(\text { Diameter })(\mathrm{cm})\end{array}$ & $\begin{array}{c}\text { Jumlah cabang } \\
\text { (Number of branch) }\end{array}$ \\
\hline 1 & 3,5 & 3,1 & 3 \\
\hline 2 & 4,3 & 4,1 & 3 \\
\hline 3 & 5,5 & 7,0 & 3 \\
\hline 4 & 4,7 & 7,9 & 5 \\
\hline 5 & 4,6 & 5,0 & 3 \\
\hline 6 & 4,1 & 4,7 & 3 \\
\hline 7 & 5,2 & 4,4 & 2 \\
\hline 8 & 4,5 & 4,7 & 2 \\
\hline 9 & 7,0 & 8,5 & 3 \\
\hline 10 & 3,2 & 3,5 & 3 \\
\hline 11 & 5,0 & 6,3 & 2 \\
\hline 12 & 4,3 & 6,0 & 3 \\
\hline
\end{tabular}

Selama 6 tahun terakhir, pertumbuhan
tinggi mencapai $0,65 \mathrm{~m}$ sedangkan diameter $0,46 \mathrm{~cm}$ (Gambar 1). Apabila dihitung dari

\section{Analisis data.}

Data hasil pengukuran pertumbuhan dianalisis deskriptif dan dibandingkan dengan data rata-rata tahun sebelumnya (Rayan, 2015). Hasil pengamatan serangan ulat dan identifikasi jenisnya dianalisis secara deskriptif.

\section{HASIL DAN PEMBAHASAN}

\section{A. Hasil}

\section{Karakteristik pohon induk pasak bumi}

Rata-rata tinggi pasak bumi mencapai 4,65 $\mathrm{m}$ dan rata-rata diameter 5,43 $\mathrm{cm}$ dengan variasi antar pohon seperti pada (Tabel 1). Kondisi tanaman sebagian besar memiliki 2-3 cabang dan hanya satu pohon yang terdapat 5 cabang. Dengan adanya cabang tersebut, pembungaan dan pembuahan dapat terjadi pada masing-masing cabang sekaligus maupun tidak.
Selama 6 tahun terakhir, pertumbuhan 110 


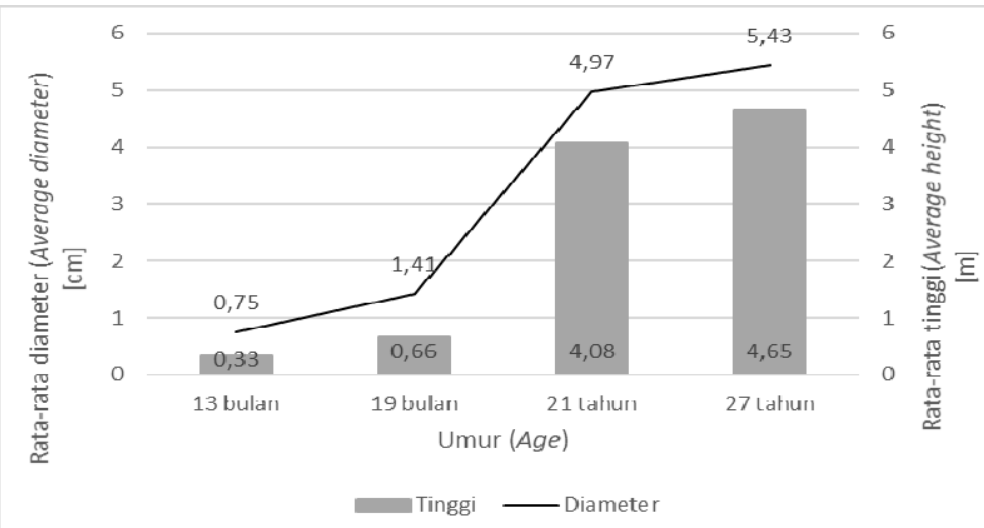

Sumber data (data source) : (Rayan, 2015)

Gambar (Figure) 1. Rata-rata tinggi dan diameter pasak bumi (Height and diameter average of pasak bumi)

\section{Pembungaan, pembuahan dan serangan ulat}

Pada periode November 2019 sampai dengan Mei 2021, terjadi pembungaan dan pembuahan sebanyak 6 kali. Musim berbunga massal terjadi pada bulan November 2019, dimana sebanyak 91,6\% tanaman mengalami pembungaan. Pembungaan paling sedikit terjadi pada September 2020 yaitu hanya terdapat 1 pohon saja. Hasil pengamatan menunjukkan bahwa, tidak semua tanaman yang berbunga mengalami pembuahan. Pada setiap masa berbunga, pohon yang berbuah hanya 1 (November 2019 dan April 2020) dan maksimal 2 pohon (Mei 2021). Bahkan periode September-Desember 2020 tidak terdapat satupun pasak bumi yang berbuah, meskipun mengalami pembungaan. Secara keseluruhan, pohon yang berhasil berbuah hanya 3 saja yaitu pohon nomor 3,9 dan 11 . Khusus pohon nomor 11 berbuah sebanyak 2 kali yaitu pada periode November 2019 dan
April 2020. Hasil pengamatan bahwa terdapat serangan ulat pada setiap masa pembungaan. Serangan paling sedikit terjadi pada bulan November 2020, sedangkan terbanyak bulan November 2019. Bahkan, pada periode September-Desember 2020 semua tanaman yang berbunga maupun yang tidak berbunga terjadi serangan ulat. Sebagian besar tanaman pasak bumi mengalami serangan berulang dengan frekuensi 2-6 kali selama pengamatan. Dinamika hasil pengamatan seperti pada Gambar 2.

Serangan ulat pada tanaman pasak bumi mencakup daun, bunga maupun buah. Serangan pada daun bervariasi antar pohon bahkan ada yang mencapai $50 \%$ dari keseluruhan tajuk. Serangan ulat pada daun ditandai dengan adanya daun yang kering pada pucuk tanaman. Daun pada pucuk mengering dan rontok kemudian diikuti keseluruhan tangkai daun rontok, sehingga pucuk menjadi gundul (Gambar 3). 


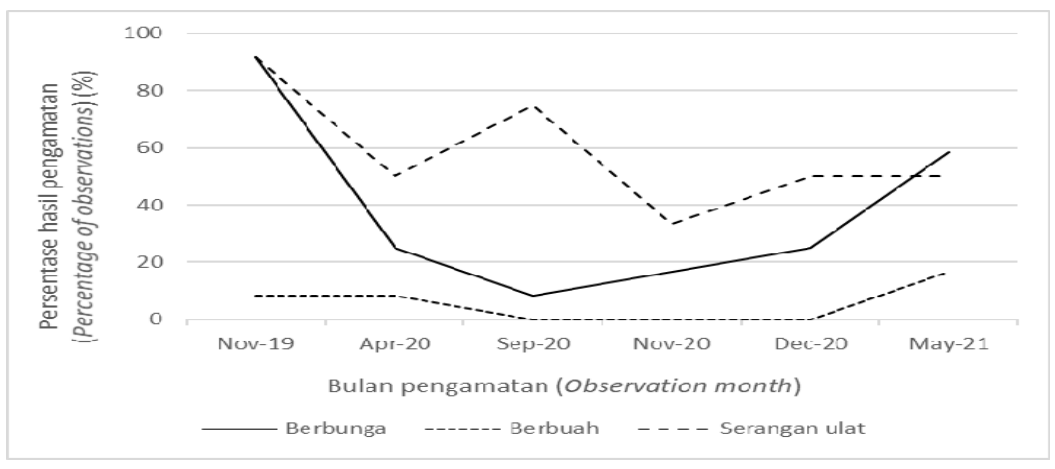

Gambar (Figure) 2. Persentase jumlah pohon pasak bumi yang berbunga, berbuah dan terkena serangan ulat (Percentages of pasak bumi that flower, bear fruit and have caterpillar infestation)

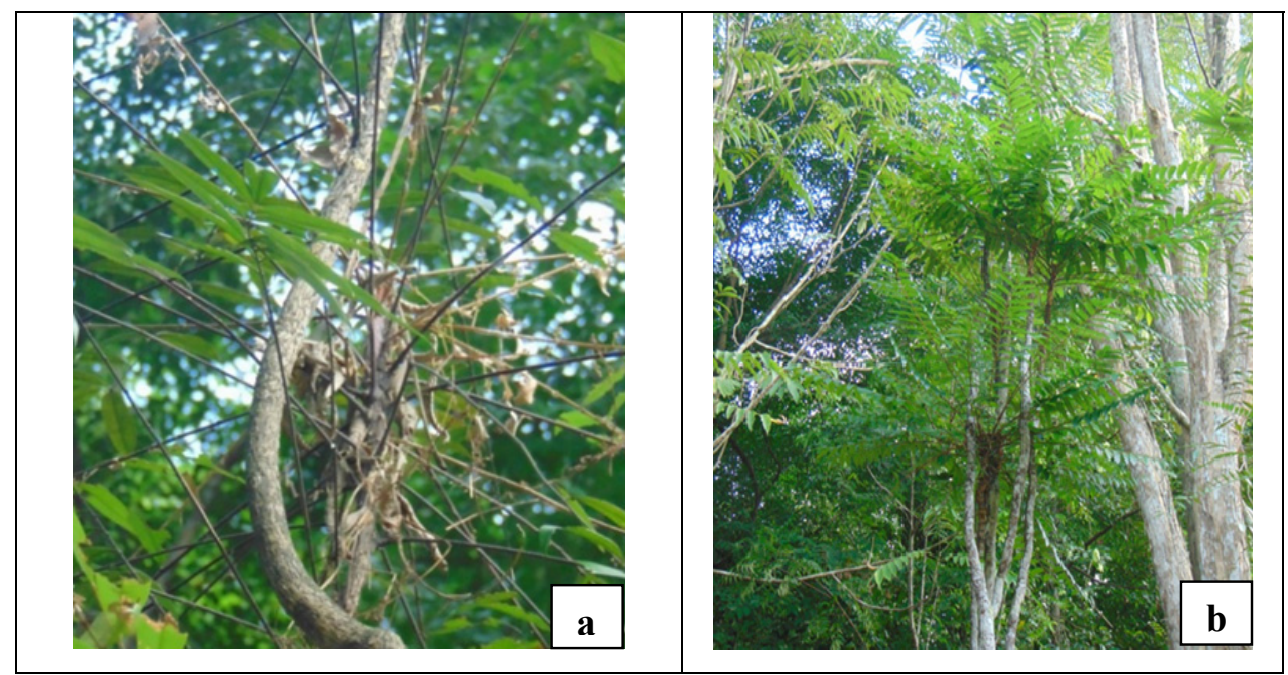

Gambar (Figure) 3. Perbandingan tanaman pasak bumi yang diserang daunnya (a) dan daun yang telah bertunas kembali (b) (Comparison of pasak bumi plants attacked by leaves (a) and leaves that have sprouted again (b))

Pada bunga, ulat menyerang secara berkelompok dengan mengeluarkan benangbenang seperti benang kusut yang berfungsi untuk memudahkan pergerakan ulat memakan bunga. Bunga-bunga pasak bumi yang sudah diserang berubah warna menjadi kehitaman dan kering. Ulat/larva menjadi pupa dan menempel pada benang-benang tersebut dan selanjutnya pupa akan menjadi imago. Bungabunga yang kering ini lambat laun akan rontok dan hilang bila terkena air hujan (Gambar 4). Serangan ulat pada buah, selain menjadikan buah pasak bumi jatuh pada waktu masih muda, juga terdapat serangan ulat pada kulit daging buah. Ulat-ulat akan memakan kulit daging pada buah yang masih muda dan buah yang sudah masak. Dampak yang ditimbulkan bila ulat menyerang pada buah yang muda adalah buah akan jatuh kelantai hutan dan tidak akan berkecambah (Gambar 5). 


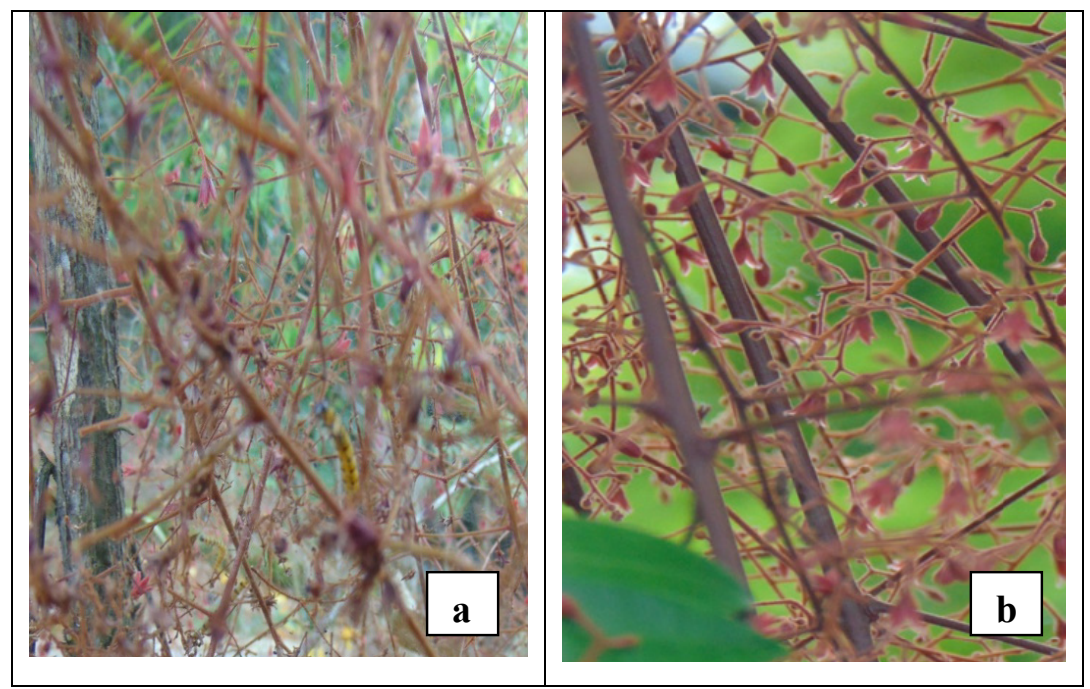

Gambar (Figure) 4. Bunga yang masih sehat berwarna kemerahan (a) dan bunga yang diserang ulat berwarna kehitaman (b) (Flowers that are still healthy are reddish (a) and flowers that are attacked by caterpillars are black (b))

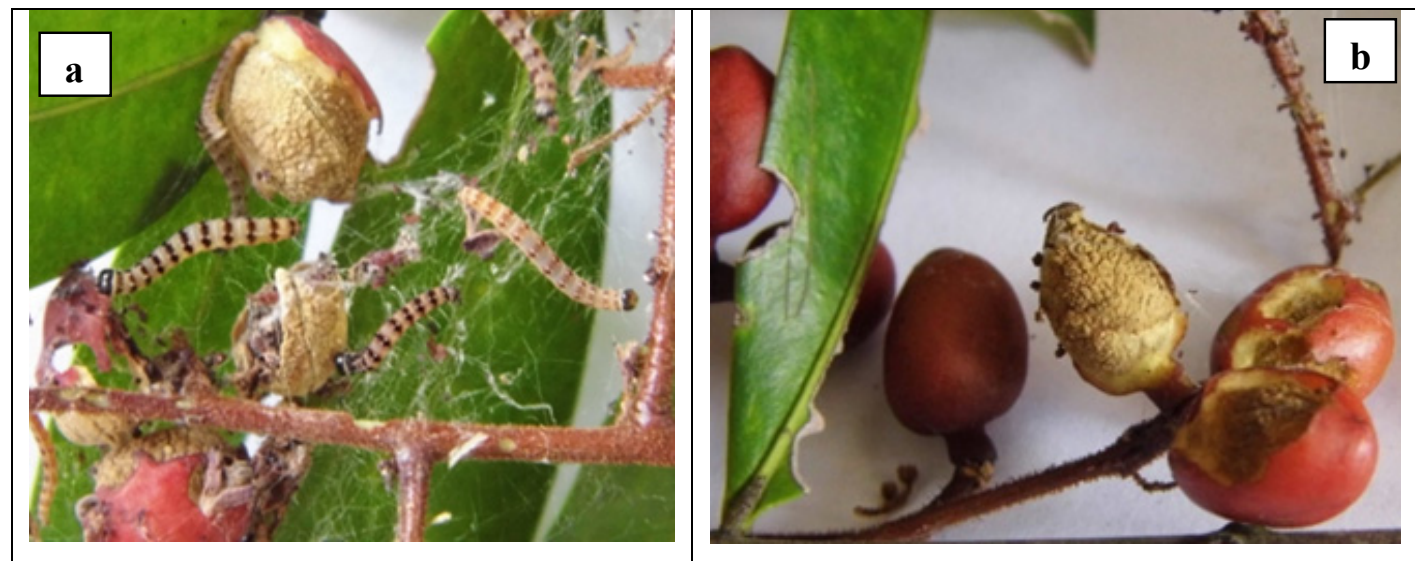

Gambar (Figure) 5. Kerusakan buah yang disebabkan ulat (Fruit's damage caused by caterpillars)

\section{Identifikasi Hama}

Hasil identifikasi ulat yang menyerang tanaman pasak bumi adalah jenis Atteva sciodoxa. Termasuk dalam famili Yponomeutidae dan ordo Lepidoptera. Larva/ulat berwarna putih kotor dan bagian tubuhnya terdapat bintik-bintik hitam. Panjang larva mencapai $16 \mathrm{~mm}$. Pupa berwarna kuning dengan panjang mencapai $14 \mathrm{~mm}$. Imago berwarna kuning kecoklatan bercampur bercak-bercak warna putih kotor pada kedua sayapnya. Panjang rentangan sayap mencapai $25 \mathrm{~mm}$. Imago mempunyai sepasang antena dan serta masa imago mencapai 5 hari (Gambar 6). 


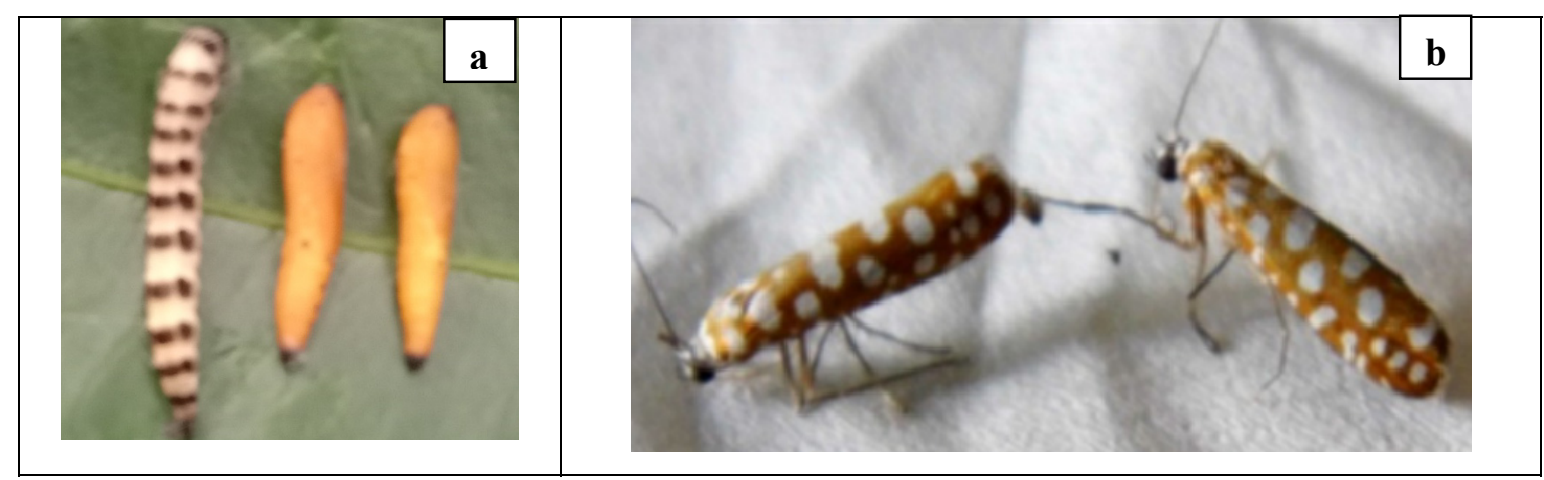

Gambar (Figure) 6. A. sciodoxa larva dan pupa (A. sciodoxa larva and cocon) (a); A. sciodoxa dewasa (‥ sciodoxa imago) (b)

\section{B. Pembahasan}

Variasi pertumbuhan pasak bumi yang terdapat di arboretum Sempaja dimungkinkan dipengaruhi oleh perbedaan pohon induk asal benih, mengingat asal benih yang digunakan dari populasi yang sama namun dari 5 pohon induk yang berbeda (Rayan, 2015). Variasi antar pohon induk tersebut menyebabkan karakter pertumbuhan yang berbeda dan diwariskan pada keturunannya melalui benih. Sistem perkawinan pasak bumi dengan penyerbukan silang (Rosmaina \& Zulfahmi, 2013) menyebabkan terjadinya variasi genetik antar pohon dalam populasi menjadi tinggi. Dimungkinkan bahwa antar pohon induk dalam populasi Mentoko memiliki keragaman genetik yang lebih tinggi jika dibandingkan dengan populasi diluarnya, seperti yang terjadi pada beberapa populasi pasak bumi di Sumatera (Rosmaina \& Zulfahmi, 2013) maupun di Malaysia (Osman et al., 2003).

Selain faktor genetik asal pohon induk, variasi pertumbuhan juga disebabkan faktor lingkungan tempat tumbuh yang mempengaruhi aktivitas fisiologi. Diantara berbagai faktor lingkungan, intensitas cahaya diduga lebih berperan mempengaruhi pertumbuhan tanaman. Tanaman pasak bumi berada di bawah tegakan sungkai (Peronema canescens) dengan jarak antar tanaman selebar 3 m. Variasi tutupan tajuk sungkai memberikan perbedaan intensitas cahaya, kualitas cahaya dan lamanya penyinaran yang diterima oleh pasak bumi sehingga mempengaruhi pertumbuhan melalui proses fotosintesis. Penyerapan cahaya oleh pigmenpigmen akan mempengaruhi pembagian fotosintat ke bagian-bagian lain dari tanaman melalui proses fotomorfogenesis (Weller \& Kendrick, 2015).

Pertumbuhan pasak bumi di arboretum Sempaja tergolong lambat yang hanya mencapai $0,17 \mathrm{~m} /$ tahun untuk tinggi dan diameter 0,2 cm/tahun. Namun di beberapa lokasi lain, variasi pertumbuhan tinggi pasak bumi juga berkisar antara 0,17-0,34 m/tahun seperti di Samboja Kaltim 0,17 m/tahun (Supartini \& Cahyono, 2020) dan Malaysia 
0,26-0,28 $\mathrm{m} /$ tahun (Iskandar et al., 2014); 0,19-0,34 m/tahun (Fadilah et al., 2016). Akar pasak bumi menjadi bagian yang paling banyak dimanfaatkan. Maka dengan mengetahui tinggi tanaman, akan dapat mengestimasi potensi akar pasak bumi yang akan didapatkan (Kartikawati et al., 2014b).

Musim berbunga dan berbuah pasak bumi di arboretum Sempaja cenderung terjadi sepanjang tahun. Hasil pengamatan menunjukkan bahwa musim berbunga dan berbuah masal terjadi pada November 2019. Berdasarkan pengamatan hanya terdapat 2 pohon yang berhasil berbuah, meskipun pada asal pengambilan benihnya telah diseleksi dan dipilih dari pohon yang berbuah saja. Kondisi ini seperti yang terjadi pada lokasi asal benihnya di Mentoko, yaitu dari 26 pohon induk yang berbunga, hanya 5 yang menghasilkan buah (Rayan, 2015). Serangan ulat merupakan faktor utama yang menyebabkan rendahnya fruit set hingga terjadi kegagalan dalam pembuahan. $A$. sciodoxa menyerang baik bagian daun, bunga serta buah pasak bumi kecuali batang akar, sehingga tajuk menjadi gundul dan proses pembuahan tidak terjadi. Ulat jenis $A$. sciodoxa tidak hanya menyerang pasak bumi di arboretum Sempaja, namun dilaporkan juga di Peninsular Malaysia. Tingkat kerusakan yang ditimbulkan berturut-turut pada model penanaman monokultur $(58,3 \%)$, polikultur $(33,3 \%)$ dan paling rendah pada hutan alam
$(32,7 \%)$ (Wan-Muhammad-Azrul et al., 2018). Kerusakan pada daun yang ditimbulkan serangan ulat di arboretum Sempaja mencapai $58 \%$ dalam model penanaman polikultur. Meskipun tidak menyebabkan kematian tanaman, namun menjadi faktor kegagalan dalam pembuahan.

Selain serangan ulat, perlu dilakukan pengamatan yang lebih mendalam terhadap proses penyerbukan yang kemungkinan menyebabkan rendahnya pembuahan. Disebutkan bahwa pasak bumi memiliki dua tipe pembungaan yaitu dioeceous dan monoceous (Lim, 2016). Jenis dioeceous meliputi pohon jantan dan pohon betina sedangkan monoceous berkelamin tunggal. Pohon jantan dapat menghasilkan buah namun gugur pada saat muda, sedangkan pohon betina mampu menghasikan benih (Padua et al., 1999). Sumber lain menyebutkan bahwa $E$. longifolia memiliki bunga berkelamin tunggal yaitu jantan dengan putik selalu steril dan sebaliknya bunga betina denga benang sari selalu steril (Rosmaina \& Zulfahmi, 2013). Indentifikasi mendalam terkait pembungaan akan dapat menentukan tindakan pengelolaan yang tepat untuk memaksimalkan perolehan benih pasak bumi.

Siklus hidup ulat $A$. sciodoxa berkisar antara 34-52 hari, yang terdiri dari periode telur (5-8 hari), larva (19-22 hari), pupa (5-7 hari) dan periode dewasa (5-19 hari) dan kemampuan ulat betina menghasilkan telur 
mencapai 106 butir atau dapat menghasilkan maksimal 20 telur per hari yang ditempelkan di bawah permukaan daun yang masih muda (Abood et al., 2009). Dengan daya menetas sebesar 81\% (Abood et al., 2009), maka jumlah ulat yang menyerang pasak bumi akan sangat banyak. Oleh karena itu, untuk dapat memperoleh buah perlu dilakukan tindakan pengendalian hama ulat A. sciodoxa. Pengendalian dapat dengan cara biologi menggunakan jamur Isaria fumosorosea dan Metarhizium anisopliae (Sajap et al., 2014). Upaya pengendalian sebaiknya dilakukan sejak serangan masih sedikit serta pengendalian dilakukan terus menerus mengingat perkembangbiakannya sangat masif.

\section{KESIMPULAN}

Tanaman pasak bumi di Arboretum Sempaja umur 25 tahun dengan rata-rata tinggi 4,65 $\mathrm{m}$ dan diameter $5,43 \mathrm{~cm}$ mengalami periode pembungaan setiap tahun. Sebagian besar tanaman dapat berbunga namun hanya 3 pohon saja yang menghasilkan buah. Pada setiap periode pembungaan, terjadi serangan ulat Atteva sciodoxa yang menyerang daun, bunga dan buah. Tidak ada tanaman pasak bumi yang terbebas dari serangan ulat. Sebagian besar tanaman mengalami serangan berulang dengan frekuensi yang bervariasi. Dampak yang ditimbulkan dari serangan ulat, mengakibatkan kegagalan dalam pembuahan dan tajuk yang gundul namun tidak menyebabkan kematian tanaman.

Perlu dilakukan tindakan pengendalian hama ulat untuk memaksimalkan perolehan benih. Disamping itu, pengamatan pembungaan dalam upaya memaksimalkan penyerbukan maupun kegiatan penyerbukan buatan sehingga terjadi pembuahan masal.

\section{UCAPAN TERIMA KASIH}

Penulis mengucapkan terima kasih kepada pengelola Arboretum Sempaja Balai Besar Penelitian dan Pengembangan Ekosistem Hutan Dipterokarpa yang telah mendukung kegiatan penelitian ini.

\section{DAFTAR PUSTAKA}

Abood, F., Bajwa, G. A., \& Ibrahim, Y. B. (2009). Developmental biology of the tiger moth, Atteva sciodoxa Meyrick (Lepidoptera: Yponomeutidae) under laboratory conditons. Journal of Biological Sciences, 9(5), 458462. https://doi.org/10.3923/jbs.2009.458.463

Achmad, B. (2016). Efektivitas rooton-f, air kelapa muda dan ekstrak bawang merah dalam merangsang pertumbuhan stek batang pasak bumi. Jurnal Hutan Tropis, 4(3), 224-231. https://doi.org/http://dx.doi.org/10.20527/jht. v4i3.3615

Andasari, P., \& Navia, Z. I. (2019). Studi dan pola distribusi pasak bumi (Eurycoma longifolia Jack) di ekowisata Bukit Lawang Taman Nasional Gunung Leuser. Jurnal Biologica Samudra, $\quad 1(2), \quad 1-5$. https://ejurnalunsam.id/index.php/jbs/article/ view/1658

Cahyono, D. D. N., \& Rayan. (2016). Pengaruh komposisi media dan perbedaan populasi pada pertumbuhan cabutan pasak bumi. Jurnal Penelitian Ekosistem Dipterokarpa, 2(2), 67-72. https://doi.org/10.20886/jped.2016.2.2.67-72

Fadilah, N. W., Zaki, M., \& Lokmal, M. N. (2016). 
Breeding strategies of Eurycoma longifolia: present and futur. In B. J. Chee, M. Mastura, K. Getha, M. G. H. Khoo, J. Mailina, M. A. Adiana, \& M. S. Roshan Jahn (Eds.), Healing Power From Nature: Current Trends and Perspectives (p. 314). Ministry of Natural Resource and Environment-Forest Research Institute Malaysia-Bioeconomy Corporation.

Fitriani, S., Astiani, D., \& Wahdina. (2017). Perbanyakan tanaman pasak bumi (Eurycoma longifolia Jack) secara generatif dan vegetatif di persemaian. Jurnal Hutan Lestari, 5(1), 113-120.

https://doi.org/10.26418/jhl.v5i1.18570

Hadiah, J. T., Yuzammi, \& Purnomo, D. W. (2019). Kajian habitat dan populasi pasak bumi (Eurycoma longifolia Jack) di blok barat kawasan hutan konservasi PT Sabhantara Rawi Sentosa, Kutai Timur, Kalimantan Timur. Buletin Kebun Raya, 22(1), 31-46. http://publikasikr.lipi.go.id/index.php/buletin/ article/view/36

Hasibuan, S., Suhesti, E., \& Insusanty, E. (2016). Kajian ekologi pasak bumi (Eurycoma longifolia Jack) dan pemanfaatan oleh masyarakat di sekitar hutan larangan adat rumbio, Kabupaten Kampar Provinsi Riau. Wahana Forestra: Jurnal Kehutanan, 11(2), 112-126.

https://doi.org/10.31849/forestra.v11i2.152

Iskandar, D. D., Rosdi, K., \& Azani, M. (2014). Growth of Eurycoma longifolia on two different series of BRIS soil. In S. Rahim, H. F. Lim, M. M. H. Farhana, \& S. Mahmudin (Eds.), Proceedings of the conference on forestry and forest products research 2013 (Issue 5, pp. 316-318). Ministry of Natural Resource and Environment-Forest Research Institute Malaysia-Asia Pacific Association of Forestry Research Institutions.

Kartikawati, S. M., Zuhud, E. A. M., Hikmat, A., \& Kartodihardjo, H. (2014). Analisis Kinerja Kelembagaan Tata Niaga Pasak Bumi (Eurycoma Longifolia Jack) Yang Berkelanjutan Di Kabupaten Kubu Raya Dan Kota Pontianak, Kalimantan Barat. Jurnal Penelitian Sosial Dan Ekonomi Kehutanan, 11(2), $153-164$. https://doi.org/10.20886/jsek.2014.11.2.153164
Kartikawati, S. M., Zuhud, E. A. M., Hikmat, A., Kartodihardjo, H., \& Fuadi, M. (2014). Habitat preferences, distribution pattern, and root weight estimation of pasak bumi (Eurycoma longifolia Jack.). Jurnal Manajemen Hutan Tropika, 20(1), 43-50. https://doi.org/10.7226/jtfm.20.1.43

Lim, T. K. (2016). Eurycoma longifolia. In Edible Medicinal and Non-Medicinal Plants: Vol. 11 Modifie (pp. 250-276). Springer, Cham. https://doi.org/10.1007/978-3-319-26062419

Nielsen, E. S., \& Common, I. F. . (1991). The Insect of Australia (Second Edi). Melbourne University Press.

Osman, A., Jordan, B., Lessard, P. A., Muhammad, N., Haron, M. R., Riffin, N. M., Sinskey, A. J., Rha, C. K., \& Housman, D. E. (2003). Genetic diversity of Eurycoma longifolia inferred from single nucleotide polymorphisms. Plant Physiology, 131(3), 1294-1301. https://doi.org/10.1104/pp.012492

Padua, L. S. ., Bunyapraphatsara, N., \& Lemmens, R. H. M. J. (Eds.). (1999). Plant Resources of South East Asia No 12 (1) Medicinal and Poisonous Plants 1. Backhuys Publishers.

Rahmawati, K., Fefirenta, A. D., \& Lestari, V. B. (2019). Studi populasi dan potensi pasak bumi (Eurycoma longifolia Jack) di Kabupaten Langkat Provinsi Sumatera Utara. In S. Gono \& M. Bismark (Eds.), Prosiding Seminar Nasional Konservasi dan Pemanfaatan Tumbuhan dan Satwa Liar "Riset Sebagai Fondasi Konservasi dan Pemanfaatan Tumbuhan dan Satwa Liar Lestari (p. 537). Pusat Penelitian Biologi LIPI.

Rayan. (2015). Penanaman jenis pasak bumi (Eurycoma sp) di arboretum Sempaja dan potensinya sebagi sumber benih. In I. Yassir, T. Atmoko, \& B. S. Sitepu (Eds.), Prosiding Seminar BALITEK KSDA Tumbuhan obat dari hutan: Konservasi, budidaya dan pemanfaatan (pp. 59-66). Balai Penelitian Teknologi Konservasi Sumber Daya Alam. https://balitek-ksda.or.id/seminar-tumbuhanobat-dari-hutan/

Riyani, C. (2016). Efektifitas metode pengeringan pada pembuatan simplisia akar pasak bumi (Eurycoma longifolia Radix). Jurnal Sains 
Dan Terapan Politeknik Hasnur, 4(1), 20-26. http://ejournal.polihasnur.ac.id/index.php/phs sains/article/view/237

Robinson, G. S., Tuck, K. R., \& Shaffer, M. (1994). A Field Guide to the Smaller Moths of South-East Asia. Malaysian Nature Society Malaysia and The Natural History Museum London.

Rosmaina, \& Zulfahmi. (2013). Genetic diversity of Eurycoma longifolia Jack based on random amplified polymorphic DNA marker. Jurnal Manajemen Hutan Tropika, XIX(2), 138-144.

https://doi.org/10.7226/jtfm.19.2.138

Rosmaina, Zulfahmi, Sutejo, P., Ulfiatun, \& Maisupratina. (2015). Induksi kalus pasak bumi (Eurycoma longifolia Jack) melalui eksplan daun dan petol. Jurnal Agroteknologi, 6(1), 33-40. https://doi.org/10.24014/ja.v6i1.1567

Sajap, A. S., Rozihawati, Z., Omar, D., \& Lau, W. H. (2014). Isaria fumosorosea and Metarhizium anisopliae for controlling Atteva sciodoxa (Lepidoptera: Yponomeutidae), a pest of Eurycoma longifolia. Journal of Tropical Forest Science, 26(1), 84-91. https://www.frim.gov.my/publication/journalof-tropical-forest-science-jtfs/

Silalahi, M., \& Nisyawati. (2015). Etnobotani pasak bumi (Eurycoma longifolia) pada etnis Batak, Sumatera Utara. 1(4), 743-746. https://doi.org/10.13057/psnmbi/m010410

Suharti, T., Bramasto, Y., \& Yuniarti, N. (2013). Kajian pengembangan tanaman obat dalam sistem agroforestri. In D. P. Kuswantor, T. S. Widyaningsih, E. Fauziyah, \& R. Rachmawati (Eds.), Prosiding Seminar Agroforestri 2013: Agroforestri untuk pangan dan lingkungan yang lebih baik (pp. 66-71). Balai Penelitian Teknologi Agroforestry-Fak. Pertanian Univ. Brawijaya-World Agroforestry CentreMasyarakat Agroforestri Indonesia.

Supartini. (2016). Teknik pemanenan akar pasak bumi secara tradisional. In Marjenah, Y. Rayadin, \& K. Maharani (Eds.), Prosiding ekspose hasil-hasil penelitian Balai Besar Litbang Ekosistem Hutan Dipterokarpa (pp.
165-174). Balai Besar Litbang Ekosistem Hutan Dipterokarpa. https://www.diptero.or.id/sdm_downloads/pr osiding-ekspose-hasil-hasil-penelitian-tahun2016/

Supartini, \& Cahyono, D. D. N. (2020). Rendemen akar, batang dan daun pasak bumi (Eurycoma longifolia Jack) sebagai bahan baku obat herbal. Jurnal Riset Teknologi Industri, 14(2), 142-155. https://doi.org/10.26578/jrti.v14i2.5788

Susilowati, A., Supriyanto, Siregar, I. Z., \& Subiakto, A. (2012). Perbanyakan tanaman pasak bumi (Eurycoma longifolia Jack) melalui teknik stek pucuk. FORESTA Indonesian of Journal Forestry, 1(1), 25-29.

Wan-Muhammad-Azrul, W. A., Mohd-Farid, A., Lee, S. Y., Sajap, A. S., Omar, D., \& Mohamed, R. (2018). A survey on the occurrence of pests and diseases in tongkat ali (Eurycoma longifolia) plantations in Peninsular Malaysia. Journal of Tropical Forest Science, 30(3), 362-375. https://doi.org/10.26525/jtfs2018.30.3.36237 5

Weller, J. L., \& Kendrick, R. E. (2015). Photomorphogenesis and Photoperiodism in Plants. In L. O. Bjorn (Ed.), Photobiology: The Science of Light and Life (Third Edit, pp. 299-321). Springer Science+Business. https://doi.org/10.1007/978-1-4939-14685 -19

Yunas, A., Yoza, D., \& Sulaeman, R. (2017). Persebaran tumbuhan obat pasak bumi (Eurycoma longifolia Jack) di jalur utama patroli Taman Hutan Raya (TAHURA) sultan Syarif Hasyim Provinsi Riau. JOM FAPERTA UNRI, 4(1), 1-5. https://jom.unri.ac.id/index.php/JOMFAPER TA/article/view/16916

Zuhud, E. A. M., \& Hikmat, A. (2009). Hutan tropika indonesia sebagai gudang obat bahan alam bagi kesehatan mandiri bangsa. In D. Tinambunan \& A. Wibowo (Eds.), Bunga Rampai Biofarmaka Kehutanan Indonesia: dari Tumbuhan Hutan untuk Keunggulan Bangsa dan Negara (p. 200). Pusat Penelitian dan Pengembangan Hutan Tanaman. 
EVALUASI PERTUMBUHAN DAN IDENTIFIKASI JENIS HAMA PASAK BUMI (Eurycoma longifolia Jack) DI ARBORETUM SEMPAJA SAMARINDA Ngatiman, Deddy Dwi Nur Cahyono dan Lydia Suastati 